\title{
sciendo
}

Current Issues in Pharmacy and Medical Sciences

Former ly ANNALES UNIVERSITATIS MARIAE CURIE-SKLODOWSKA, SECTIO DDD, PHARMACIA

\section{Evaluation of interleukin- 6 concentration in the liver of Albino Swiss mice after intoxication with various doses of patulin}

\author{
Pawel Borzecki ${ }^{1}$, Agnieszka Borzecka ${ }^{2}$, Patrycja Chylinska-Wrzos ${ }^{1 \star}$ (ㄹ, \\ Marta Lis-SochockA ${ }^{1}$, EWElina WaWryk-GaWdA ${ }^{1}$, BARbara JodlowsKa-Jedrych ${ }^{1}$ \\ ${ }^{1}$ Chair and Department of Histology and Embryology with Experimental Cytology Unit, Radziwillowska 11, 20-080 Lublin, Poland \\ ${ }^{2}$ Chair and Department of Epidemiology and Clinical Research Methodology, Chodzki 1, 20-093 Lublin, Poland
}

\section{ARTICLE INFO}

Received 20 May 2018

Accepted 06 July 2018

\section{Keywords:}

patulin, mycotoxin,

interleukin 6,

mice,

liver.

\begin{abstract}
Patulin is a mycotoxin produced by many species of the fungi. The toxic action of patulin mainly affects the gastrointestinal tract and the immune system. The aim of our work was to assess the toxic effect of patulin, based on the analysis of interleukin IL-6 concentrations in the liver of test animals loaded with different doses of this mycotoxin. The research was conducted on mice which were assigned to 6 groups receiving different doses of active substances. After decapitation, their livers were taken for laboratory testing.

Our studies have shown that chronic intoxication with patulin at $0.1 \mathrm{LD} 50$ leads to a statistically significant increase in IL- 6 concentration in the liver of the animals. We also found that the loading of experimental animals with a single dose of patulin in the amount of 0.5 LD50 and 0.2 LD50 also leads to a statistically significant increase in this interleukin in the examined organ. There was no difference in its concentration compared to the control group only after the single dose of the lowest concentration of patulin, while the highest average IL- 6 concentration was recorded in the liver of animals loaded with the highest single dose of patulin. After applying, one-time doses of this mycotoxin in the amount of 0.2 LD50 and 0.1 LD50, the mean concentrations of IL-6 in the liver in animals from these groups were statistically significantly lower.

In conclusion, the analysis of the obtained results confirms the fact of the hepatotoxic effect of patulin.
\end{abstract}

\section{INTRODUCTION}

Patulin is a mycotoxin which was first isolated in 1943 by Birkinshaw et al. [1] from the culture of the fungus Penicillium patulum as an antibiotic. In subsequent years, this mycotoxin was received in various laboratories, and various researchers gave it different names. These were: penicidin, claviformin, harvnin, expansin, gigantic acid [1-4].

Patulin is produced by many species of the fungi Penicillium and Aspergillus. However, Penicillium expansum is the most important. Patulin-producing fungi can be found in many food products such as fruits, vegetables, cereal grains, meat and meat products, cheese and bread. The optimal development of these fungi occurs at a relative humidity of $80-90 \%$ [1].

\footnotetext{
* Corresponding author

e-mail: patrycja.wrzos@umlub.pl
}

Penicillium expansum is a species that is especially common in perishable fruits: apples, pears, grapes, slightly less in bananas, cherries, nectarines, apricots and pineapples, as well as in vegetables, mainly in tomatoes. A significant percentage of Penicillium expansum strains have the ability to produce even very large amounts of patulin. Patulin contaminates not not only fruits and vegetables, but also food products made from them. This applies mainly to apple juice, fruit wines from apples, compotes and jams [2,3,5-8]. In standard industrial processing, patulin passes into juices, fruit concentrates and other preserves. The studies of Szymczyk et al. [9] have demonstrated the presence of patulin in concentrations exceeding the upper limit of the acceptable standard in more than $1 \%$ of the tested apple juices.

Recommendations on the highest permissible concentration of patulin in food products in the European Union 
countries are put forward by the Commission Regulation (WE) No. 1881/2006 of 19 December, 2006, amending the 2003 regulation $[10,11]$. This applies mainly to products obtained from apples. For fruit juices and nectars that are mostly apple-based, the maximum permissible level of patulin is $50.0 \mu \mathrm{g} / \mathrm{kg}$. For alcoholic beverages obtained from apples or with apple juice, the level of patulin is also $50.0 \mu \mathrm{g} / \mathrm{kg}$. For solid products obtained from apples, including purees and compote, a level of $25.0 \mu \mathrm{g} / \mathrm{kg}$ applies. Finally, the maximum permissible level of patulin in apple juice and solid apple products intended for children and in other food for children is $10 \mu \mathrm{g} / \mathrm{kg}[10,11]$.

Patulin is a very reactive compound and easily binds to proteins and nucleic acids. This is the cause of its harmfulness to living organisms $[1,3]$. Patulin is stable in an acid environment, it does not break down at $\mathrm{pH}$ 3.0-6.5, thus, in processes that are used in the production of food, patulin is not completely degraded. Furthermore, it is resistant to pasteurization and sterilization. Although alcoholic fermentation breaks down patulin, it may be present in alcoholic drinks produced from apples if apple juice is added to the product after fermentation $[9,12]$.

Patulin exhibits a variety of effects on living organisms. This toxin can damaged a number of organs and tissues [1,13-20], and the toxic effect of patulin may be acute, subacute and chronic. What is more, the toxicity of patulin is 3-6 times higher after its intravenous, intraperitoneal or subcutaneous administration. Of note: subacute and chronic poisoning is the result of constant exposure to intoxication even with small doses over a longer period of time [1].

The toxic action of patulin mainly affects the gastrointestinal tract. Patulin damages the intestinal mucosa. This leads to the degeneration of the epithelial cells, and, consequently, is the cause of chronic inflammation, ulceration and gastrointestinal bleeding $[21,22]$. In addition, it can lead to disturbance of intestinal motility and abnormalities in the production of digestive enzymes [15]. Patulin also damages liver cells. This affects the activity of liver enzymes [14,23-25].

What is more, it has been shown that patulin affects the immune system of the body as it leads to changes in the production and function of lymphocytes. It also causes an increase in the number of cytotoxic $\mathrm{T}$ lymphocytes, impaired production of immunoglobulins (mainly immunoglobulin G) and an increase in the amount of neutrophils and monocytes. Moreover, it inhibits the function of macrophages. Furthermore, patulin affects the production of cytokines and it inhibits the interferon gamma, interleukin 4, 10 and 13 secretion by human monocytes and $\mathrm{T}$ lymphocytes [26,27].

Interleukins (IL) are mainly produced by leukocytes, but they can also be produced by fibroblasts, endothelial cells, adipocytes, and cells of the colon and bone marrow [28].

IL-6 is a cytokine with multidirectional effects. It mainly works on B-lymphocytes, stimulating the differentiation of these cells and the production of immunoglobulins by them. IL-6, together with IL-1, also activates T-lymphocytes recognizing antigens and stimulates the formation and differentiation of cytotoxic lymphocytes. IL-6 is considered an early and sensitive indicator of inflammatory reactions.
It is the basic stimulator of acute phase protein synthesis in the liver, mainly CRP protein. In inflammatory conditions, the concentration of IL- 6 in the serum of patients increases many times. IL-6 also has a pyrogenic effect. Together with IL-1, TNF and INF, this cytokine can significantly increase body temperature [29,30-32] by stimulating prostaglandin production. Increased IL-6 production and sustained high serum concentration of this cytokine promote the passage of an acute inflammatory reaction into the chronic phase, which contributes to the development of many diseases [33].

The inhibition of protein synthesis by patulin adversely affects the mitotic divisions of rapidly dividing cells of the immune system, and adversely affects the systemic immune system, both cellular and also humoral. Furthermore, it significantly reduces the body's resistance to bacterial, viral, as well as fungal infections [34].

The aim of our work was to assess the toxic effect of patulin, based on the analysis of interleukin IL-6 concentrations in the liver of test animals loaded with different doses of this mycotoxin.

\section{MATERIAL AND METHODS}

The research was conducted on mice - females of the Albino Swiss with a body weight of 20-24 g. These were randomly assigned to the different groups. The use of females in the experiment was aimed at eliminating the fight for territory by males and the unpleasant odors emitted. During the experiment, the animals were maintained under standard laboratory conditions. Prior to the research, the consent of the Local Ethics Commission of the Medical University in Lublin was obtained for conducting experiments on animals for scientific purposes (No. 22/2013).

The experimental animals were divided into 6 groups of 6 animals each, which received different doses of active substances intraperitoneally according to different schemes (Tab. 1).

Table 1. Schedule of administration of active substances to the animals

\begin{tabular}{|l|c|}
\hline $\begin{array}{c}\text { Animal } \\
\text { group }\end{array}$ & Dose of the active substance administered intraperitoneally \\
\hline $\begin{array}{l}\text { Group } 1 \\
\text { (control) }\end{array}$ & $0.9 \% \mathrm{NaCl}$ solution given once daily for 28 days \\
\hline Group 2 & Patulin in a dose of 0.1 LD50* given once a day for 28 days \\
\hline Group 3 & A single dose of patulin in amount of 0.5 LD50* \\
\hline Group 4 & A single dose of patulin in amount of 0.2 LD50* \\
\hline Group 5 & A single dose of patulin in amount of 0.1 LD50* \\
\hline $\begin{array}{l}\text { Group 6 } \\
\text { (control) }\end{array}$ & $0.9 \%$ NaCl solution in a single dose \\
\hline
\end{tabular}
chemical compound

The LD50 value is the dose needed to cause the death of $50 \%$ of animals of a specific species. For the AlbinoSwiss white mice used for own studies, LD50 for patulin corresponds to a dose of $10 \mathrm{mg} / \mathrm{kg}$ m.c. $[35,36]$.

After decapitation of the animals, the liver for laboratory tests was taken from them. The liver was homogenized in PBS buffer - a concentrated, buffered saline solution (Phosphate-Buffered Saline from GIBCO $^{\circledR}$ ) in the proportions: 0.5 $\mathrm{g}$ of material per $2 \mathrm{ml}$ of buffer. The prepared homogenate was then centrifuged for 15 minutes at $14.000 \mathrm{~min}$. at $4^{\circ} \mathrm{C}$. In the obtained supernatants, the IL- 6 concentration was 
determined by means of an ELISA reader using the CloudClone Corp kit (USA).

\section{Statistical analysis}

The obtained results were statistically developed and are presented as tables and figures. The arithmetic mean \pm standard deviation, the minimum and maximum values were calculated. In order to apply the appropriate statistical tests, We first ascertained whether the obtained test results are distributed according to the normal distribution. In the absence of normal distribution or non-uniform variance, non-parametric methods were used.

Significance of differences between IL- 6 concentration in the liver of animals subjected to patulin intoxication and the concentration of this cytokine in the liver of animals from control groups was assessed using the U Mann-Whitney test. The assessment of the significance of changes in IL-6 concentrations in the liver of the test animals after the administration of different doses of patulin was achieved using Kruskal-Wallis's ANOVA test. In contrast, a post-hoc Dunn test was used to perform a detailed analysis of multiple comparisons regarding differences between individual groups of animals loaded with different doses of patulin.

Statistical results were considered statistically significant at the probability level $\mathrm{p}<0.05$.

The statistical analysis was carried out using the Statistica version 10.0 computer program from StatSoft (an academic license for the Medical University of Lublin).

\section{RESULTS}

Concentration of IL-6 in the liver of animals chronically patulin-burdened, and in animals from control group 1 (Table 2).

Table 2. Concentration of IL-6 in the liver of animals chronically patulin-burdened, and in animals from control group 1

\begin{tabular}{|c|c|c|c|c|}
\hline $\begin{array}{c}\text { Animal } \\
\text { group }\end{array}$ & $\begin{array}{c}\text { Average value } \\
\text { IL-6 (ng/ml) }\end{array}$ & $\begin{array}{c}\text { Standard } \\
\text { deviation }\end{array}$ & $\begin{array}{c}\text { Range } \\
(\min -\mathrm{max})\end{array}$ & $\begin{array}{c}\text { Statistical } \\
\text { analysis }\end{array}$ \\
\hline 1 & 137.42 & 64.81 & $61.77-218.33$ & $\mathrm{U}=9.0$ \\
\hline 2 & 305.84 & 165.66 & $117.75-658.35$ & $\mathrm{p}=0.02$ \\
\hline
\end{tabular}

In animals from the control group that had received intraperitoneal $0.9 \% \mathrm{NaCl}$ solution for 28 days, the concentration of IL- 6 ranged from $61.77 \mathrm{ng} / \mathrm{ml}$ to $218.33 \mathrm{ng} / \mathrm{ml}$, and averaged $137.42 \mathrm{ng} / \mathrm{ml}$. In contrast, in animals administered intraperitoneally patulin at a dose of 0.1 LD50, the concentration of the studied interleukin was at levels from 117.75 $\mathrm{ng} / \mathrm{ml}$ to $658.35 \mathrm{ng} / \mathrm{ml}$, and averaged $305.84 \mathrm{ng} / \mathrm{ml}$.

Statistical analysis of the results obtained by using the Mann-Whitney U test showed that the concentration of IL- 6 in the liver of animals chronically burdened with 0.1 LD50 of patulin was significantly higher $(p=0.02)$ than the values observed in control group 1 (Tab. 2).

The IL-6 concentration in the liver of animals after a single load with various doses of patulin and in animals from control group 6 is shown in Table 3. Herein, the test animals were loaded with a single dose of various patulin dose strengths as an expression of acute poisoning.

The highest concentration of IL-6 (276.62 ng/ml) was observed in the liver of animals loaded with the highest single dose of patulin (0.5 LD50). After using the lower doses of this mycotoxin: 0.2 LD50 and 0.1 LD50, IL-6 concentrations in animals from these groups were lower and amounted to $161.66 \mathrm{ng} / \mathrm{ml}$ and $80.42 \mathrm{ng} / \mathrm{ml}$, respectively. These differences as assessed by the Kruskal-Wallis test were statistically significant $(H=15.34 ; p=0.001)$ (Tab. 3).

Table 3. Concentration of IL-6 in the liver of animals loaded with various doses of patulin, as compared to animals from control group 6

\begin{tabular}{|c|c|c|c|c|}
\hline $\begin{array}{c}\text { Animal } \\
\text { group }\end{array}$ & $\begin{array}{c}\text { Average value } \\
\text { IL-6 }(\mathrm{ng} / \mathrm{ml})\end{array}$ & $\begin{array}{c}\text { Standard } \\
\text { deviation }\end{array}$ & $\begin{array}{c}\text { Range } \\
\text { (min-max) }\end{array}$ & $\begin{array}{c}\text { Statistical } \\
\text { analysis }\end{array}$ \\
\hline 3 & 276.62 & 198.16 & $117.75-658.35$ & \\
\hline 4 & 161.66 & 37.53 & $114.04-204.84$ & $\mathrm{H}=15.34$ \\
\hline 5 & 80.42 & 16.76 & $60.31-103.13$ & $\mathrm{p}=0.001$ \\
\hline 6 & 82.86 & 43.67 & $29.00-160.20$ & \\
\hline
\end{tabular}

A detailed comparative analysis carried out with the post-hoc test showed that these differences were mostly due to the results of IL- 6 concentrations in the liver between animal groups 3 and 6; 4 and 6; 3 and 5 and 4 and $5(\mathrm{p}<0.05)$.

The IL- 6 concentrations in the liver of animals loaded with a single dose of patulin: 0.5 LD50 were significantly higher $(\mathrm{p}=0.004)$ than the values observed in control group 6 (Fig. 1) and in group 5 (Fig. 2). Similarly, in group 4, the concentration of IL-6 in the liver was significantly higher $(p=0.02)$ than in the control group 6 (Fig. 3) and in group 5 $(\mathrm{p}=0.005)$ (Fig. 4).

However, the comparative analysis did not show any statistically significant differences between the IL-6 concentration in the liver of animals loaded with the lowest dose of patulin (0.1 LD50) at once in relation to animals from control group $6(\mathrm{p}=0.97)$ (Fig. 5). The differences in IL-6 concentrations between groups of animals that received patulin at $0.5 \mathrm{LD} 50$ and $0.2 \mathrm{LD} 50$ at one time were also statistically insignificant ( $p=0.07$ ) (Fig. 6).

\section{DISCUSSION}

Mold fungi are a constant element within the natural environment of man. Contact with them and with the mycotoxins which they produce is very widespread and takes place in various ways. However, it is known that food is the main source of mycotoxin intake for humans $[1,37]$, and numerous bibliographic data confirm the multidirectional, toxic effect of various mycotoxins on the human, animal and plant organisms [1,13-20]. Still, there are not many works on the harmful effects of patulin.

In the initial period of research on patulin, aspects related to its phytotoxicity were mainly addressed, and the strong antibiotic properties of patulin were made known. This mycotoxin was thus approved as an aerosol for the treatment of upper respiratory tract infections. However, in the subsequent years, its toxic effect was confirmed [15] and approval was withdrawn.

Studies conducted by various authors have confirmed the effect of patulin on the synthesis and activation of various cytokines [15,22,27,34,38,39]. Wichman et al. [27] showed a reduction in the secretion of interferon gamma and interleukin 4 by human macrophages after intoxication with patulin. 


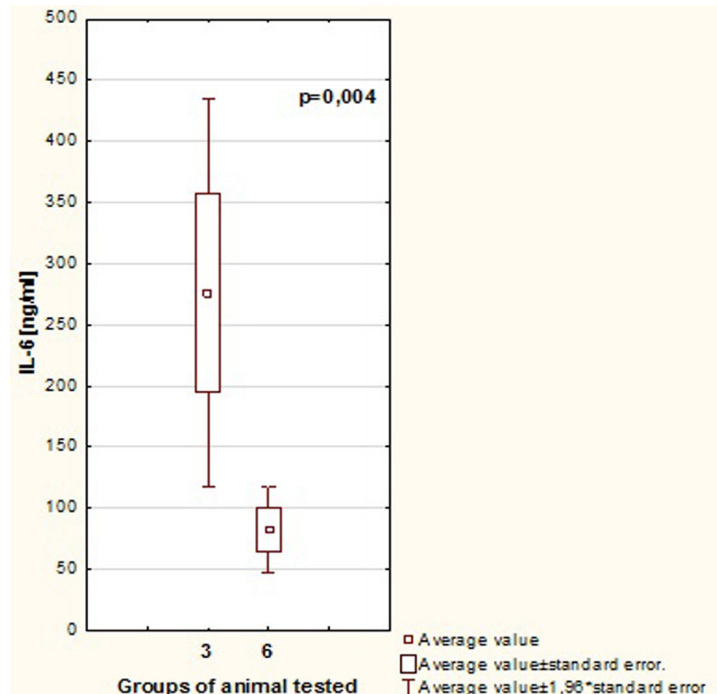

Figure 1. Comparison of IL- 6 concentrations in the liver of animals after a single load of patulin 0.5 LD50, with control group 6

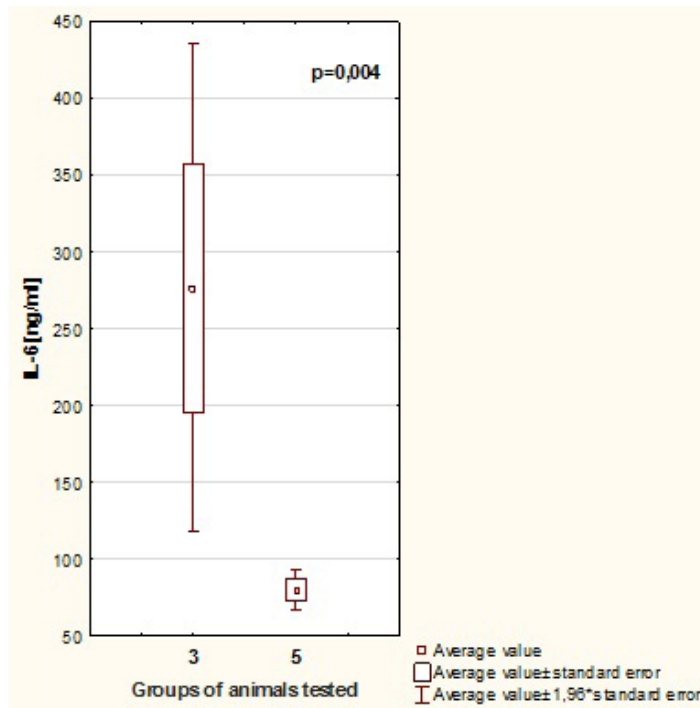

Figure. 2. Comparison of IL-6 concentrations in the liver of animals after a single load of patulin at a dose of 0.5 LD50 and 0.1 LD50.

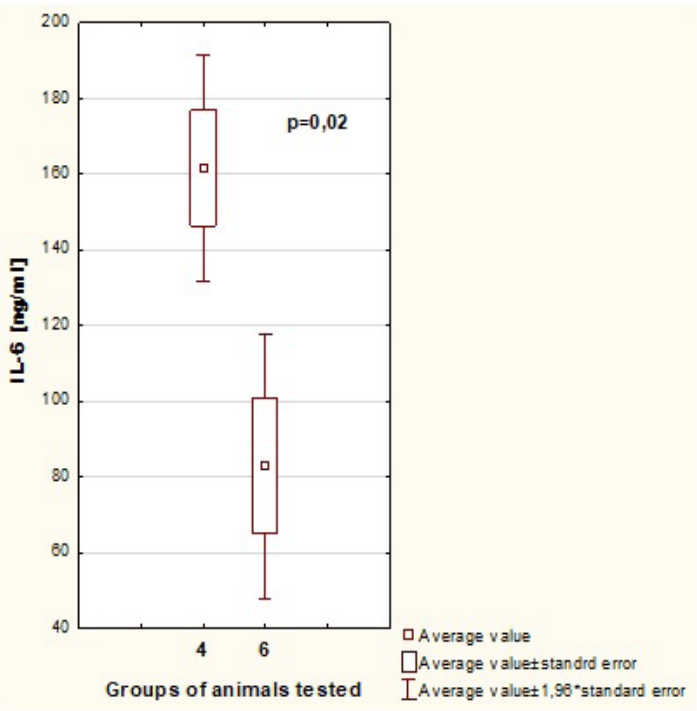

Figure 3. Comparison of IL-6 concentrations in the liver of animals after a single load of patulin 0.2 LD50, with control group 6

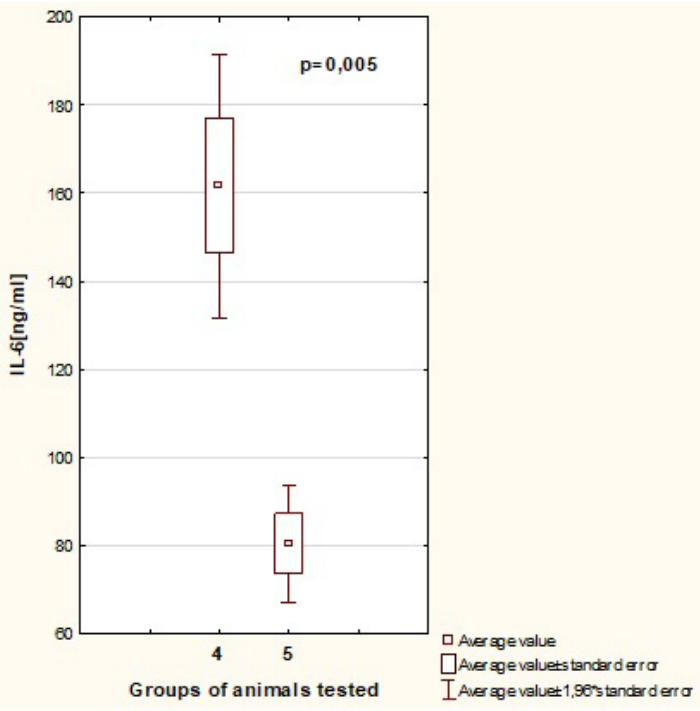

Figure 4. Comparison of IL-6 concentrations in the liver of animals after a single load of patulin 0.2 LD50 and 0.1 LD50

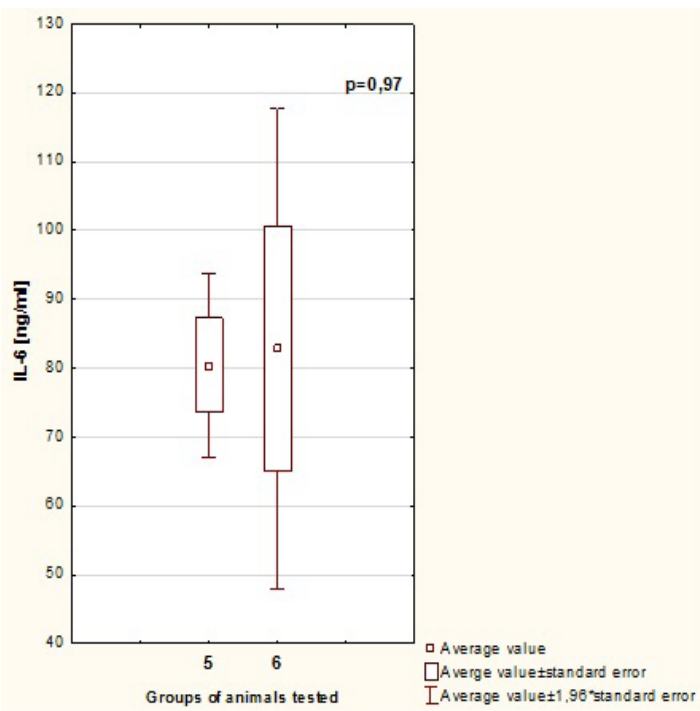

Figure 5. Comparison of IL-6 concentrations in the liver of animals after a single load of 0.1 LD50 patulin, with control group 6

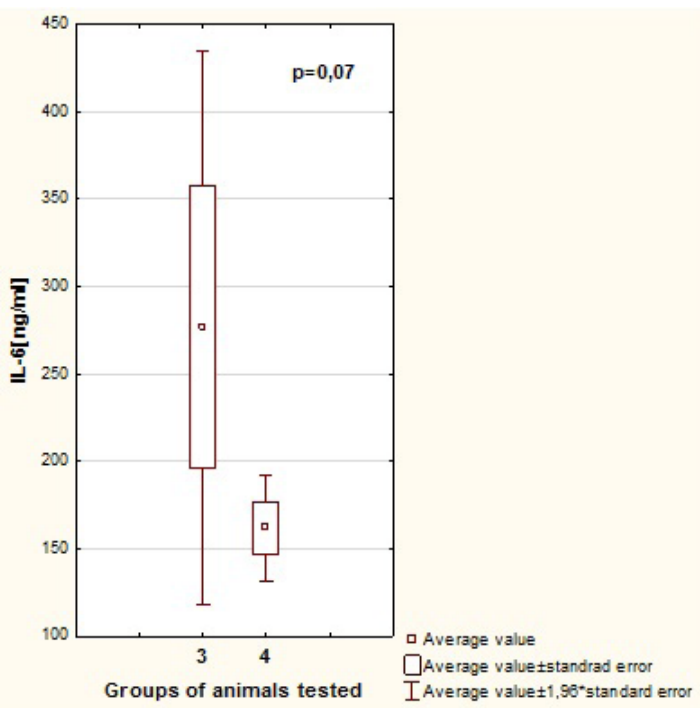

Figure 6. Comparison of IL-6 concentrations in the liver of animals after a single load of patulin at a dose of 0.5 LD50 and 0.2 LD50. 
Moreoves, Luft et al. [38] also demonstrated the inhibitory effect of patulin on the production of interleukins 2, 4, 5, 10 and 13 by human peripheral blood mononuclear cells. However, Maresca et al. [22] demonstrated a stimulatory effect of patulin on the production of interleukin 1 and 8 . Finallr, research by Bouhet et al. [15] confirmed the effect of patulin on the induction of gene expression for TNF- $\alpha$, IL-6, and for IL-1 and IL-8.

However, in the available literature of recent years, no data were found on the tests assessing IL-6 concentrations of animal liver after intoxication with various doses of patulin.

In addressing this deficit, our studies have shown that chronic intoxication with patulin at 0.1 LD50 led to a statistically significant increase in IL-6 concentration in the liver of the test animals (as compared to the control group). We also found that the loading of experimental animals with a single dose of patulin in the amount of 0.5 LD50 and 0.2 LD50 led to a statistically significant increase in this interleukin in the examined organ. Indeed, the single dose of the lowest concentration of patulin (0.1 LD50) alone showed no difference in its concentration compared to the control group.

The highest average IL- 6 concentration was recorded in the liver of animals loaded with the highest single dose of patulin (0.5 LD50). After applying, one-time doses of this mycotoxin in the amount of 0.2 LD50 and 0.1 LD50, the mean concentrations of IL- 6 in the liver in animals from these groups were statistically significantly lower. Indeed, the lowest average concentration of IL- 6 that did not differ in a statistically significant way from the values observed in the control group, was found in the liver of animals loaded with the lowest one time dose of patulin.

The obtained results confirm the hepatoxic effect of patulin. Moreover, they indicate the adverse effects of exposure to the body not only to a single, high dose of patulin (most often due to random chance), but also to intoxication with low doses of this mycotoxin, chronically-taken.

Gashlan H.M. [36], Puel et al. [1], and Song et al. [25] confirmed the hepatotoxicity of patulin, and based this on the assessment of the histopathological view of the liver and the concentration of hepatic enzymes in the serum of experimental animals. The inducing effect of patulin on the IL-6 and TNF- $\alpha$ secretion has also been demonstrated $[15,24]$.

IL-6 is considered an early and sensitive indicator of inflammatory reactions, and a number of toxins induce the production of IL-6. This reaches its maximum concentration in as little time as 3 hours after the onset of intoxication. In inflammatory conditions, the concentration of IL-6 in the serum of patients increases many times $[40,41]$.

The main effector organ of IL- 6 action is the liver, and after just 20 minutes, $80 \%$ of the labeled, recombinant human IL-6 administered to experimental animals gets into the organ. IL- 6 is localized on the surface of hepatocytes where specific receptors for this cytokine are found [42].

Increased production of IL-6, as well as long-lasting high concentration in the blood serum, promotes the passage of the acute inflammatory reaction of the body into the chronic phase. Herein, IL-6 influences the regulation of the secretion of vascular endothelial growth factor that is produced by various types of cells. This plays a fundamental role in angiogenesis and increases the permeability of blood vessels. This, in turn, affects the development and maintenance of inflammation [43-45].

The analysis of the obtained results and the available literature positions confirm the hepatotoxic effect of patulin. Most often unaware of the danger, we eat fruit contaminated with patulin, or preparations made from them, yet, one moldy fruit or vegetable, and even one pistachio or groundnut is enough to blemish the whole batch of fruits, juices, jams or other food products [2].

The various clinical symptoms that develop gradually and slowly resulting from chronic intoxication with low doses of mycotoxins can remain unnoticed for a long period of time. In such situations, the full clinical manifestation of mycotoxicosis often occurs when the damage to a wide range of tissues and organs is very extensive and sometimes irreversible. In addition, co-existing other diseases of the body, the current state of nutrition and the taken drugs can change the metabolism of mycotoxins, intensify their toxic action, and effect the clinical picture of poisoning. These factors significantly hinder the diagnosis and delay the implementation of appropriate therapeutic procedures. Therefore, it is important to monitor mycotoxin concentrations in products consumed by humans and in animal feeds. It is also necessary to conduct educational activities aimed at promoting issues concerning mycotoxins, their occurrence in the natural environment of man and the risks resulting therefrom.

\section{CONCLUSION}

The results of our research indicate that not only a single exposure to a high dose of patulin (which is an expression of acute poisoning), is dangerous for the animal organism, but also the toxic effect of even small doses of this mycotoxin acting on the body in a chronic manner is worrying. So the results presented in this work require continuation. Were this undertaken, the action will contribute to not only a fuller understanding of the mechanisms of hepatotoxic action of patulin, but also to an understanding of the mechanisms leading to disturbances of systemic homeostasis processes which are a consequence of mycotoxin intoxication. It is, thus, necessary to establish a pattern of prophylactic and therapeutic actions in the case of patulin intoxication, as well as that of a number of other mycotoxins.

\section{ACKNOWLEDGMENTS}

This work is an original study presenting novel work, and it has not been previously submitted to any other journal and it has not been accepted by any other journal.

This work has been approved by all authors.

Permission was given by the local Bioethical Committee of the Medical University in Lublin to conduct the experiments of this study (No. 22/2013).

Authors declare no conflict of interest.

This work was founded by research no MNmb245, Medical University in Lublin, Poland.

\section{ORCID iDs}

Patrycja Chylińska-Wrzos Dhttps://orcid.org/0000-0003-1666-0225 Barbara Jodłowska-Jędrych (Dhttps://orcid.org/0000-0003-3483-8752 


\section{REFERENCES}

1. Puel O, Galtier P, Oswald IP. Biosynthesis and Toxicological Effects of Patulin. Toxins. 2010;2(4):613-31.

2. Bennet JW, Klich M. Mycotoxins. Clin Microbiol Rev. 2003;16(3):497-516.

3. Chełkowski J. Mikotoksyny, grzyby toksynotwórcze i mikotoksykozy. http://www.cropnet.pl/dbases/mycotoxins.pdf.pl/download. 2010, [accessed 2010 June 20].

4. Wilson DM, Mubatanhema W, Jurjevic Z. Biology and ecology of mycotoxigenic Aspergillus species as related to economic and health concerns. Adv Exp Med Biol. 2002;504:1-17.

5. Balas J. Mikotoksyny jako źródło zanieczyszczeń żywności pochodzenia roślinnego. Postepy Fitoterapii. 2006;2:98-104.

6. Grajewski J. Mikotoksyny i grzyby pleśniowe. Zagrożenie dla człowieka i zwierzat. Bydgoszcz. Wyd. UKW, 2006.

7. Jarzynka S, Dąbkowska M, Netsvyetayeva I, Swoboda-Kopeć E Mikotoksyny - niebezpieczne metabolity grzybów pleśniowych. Medycyna Rodzinna. 2010;4:113-9.

8. Santini A, Raiola A, Meca G, Ritieni A. Aflatoxins, Ochratoxins, Trichotecenes, Patulin, Fumonisins and Beauvericin in Finished Products for Human Consumption. J Clin Toxicol. 2015;5(4):2-11.

9. Szymczyk K, Szteke B, Goszcz H. Występowanie patuliny w krajowych sokach jabłkowych. Roczn PZH. 2004;55(3):255-60.

10. Kurpińska-Jaworska J, Ledzion E, Szczęsna M, Karłowski K, Postupolski J, Rybińska K. Nowe przepisy Unii Europejskiej w zakresie patuliny. Roczn PZH. 2003;54(4): 355-61.

11. Rozporzadzenie Komisji Wspólnoty Europejskiej NR 1881/2006 z dnia 19 grudnia 2006 r. ustalające najwyższe dopuszczalne poziomy niektórych zanieczyszczeń w środkach spożywczych. L364 5-24.

12. Wróbel B. Zagrożenia zwierząt i ludzi toksynami grzybów pleśniowych zawartych w paszach i żywności. Woda-ŚrodowiskoObszary Wiejskie. 2014;14:159-76.

13. Al-Hazmi MA. Patulin in apple juice and its risk assessments on albino mice. Toxicol Ind Health. 2014;30(6):534-45

14. Arzu Koçkaya E, Selmanoğlu G, Ozsoy N, Gül N. Evaluation of patulin toxicity in the thymus of growing male rats. Arh Hig Rada Toksikol. 2009;60:411-8.

15. Bouhet S, Oswald IP. The effects of mycotoxins, fungal food contaminants, on the intestinal epithelial cell-derived innate immune response. Vet Immunol Immunopathol. 2005;108:199-209.

16. Glaser N, Stopper H. Patulin: Mechanism of genotoxicity. Food Chem Toxicol. 2012;50(5):1796-801.

17. Grajewski J, Twarużek M. Zdrowotne aspekty oddziaływania grzybów pleśniowych i mikotoksyn. Alergia. 2004;3:45-9.

18. Ozsoy N, Selmanoğlu G, Koçkaya EA, Gül N, Cebesoy S. Effect of patulin on the interdigitating dendritic cells (IDCs) of rat thymus. Cell Biochem Funct. 2008;26(2):192-6.

19. Pfeiffer E, Diwald TT, Metzler M. Patulin reduces glutathione level and enzyme activities in rat liver slices. Mol Nutr Food Res. 2005;49(4):329-36.

20. Roll R, Matthiaschk G, Korte A. Embryotoxicity and mutagenicity of mycotoxins. J Environ Pathol Toxicol Oncol. 1990;10:1-7.

21. Mahfoud R, Maresca M, Garmy N, Fantini J. The mycotoxin patulin alters the barrier function of the intestinal epithelium: mechanism of action of the toxin and protective effects of glutathione. Toxicol Appl Pharmacol. 2002;15,181(3):209-18.

22. Maresca M, Yahi N, Younès-Sakr L, Boyron M, Caporiccio B, Fantini $J$. Both direct and indirect effects account for the pro-inflammatory activity of enteropathogenic mycotoxins on the human intestinal epithelium: Stimulation of interleukin-8 secretion, potentiation of interleukin- 1beta effect and increase in the transepithelial passage of commensal bacteria. Toxicol Appl Pharmacol. 2008;228:84-92.

23. Nagasue N, Yukaya H, Ogawa Y, Kohno H, Nakamura T. Human liver regeneration after major hepatic resection. A study of normal liver and livers with chronic hepatitis and cirrhosis. Ann Surg. 1997;206:30-9.
24. Nagwa M, El-Sawi NM, Gashlan HM, Younes SH, Al-Massabi RF, Shaker S. Biochemical and histological studies on the effect of the Patulin mycotoxin on male rats' liver and treatment by crude venom extracted from jelly fish. Life Sci J. 2012;9(4):1143-53.

25. Song E, Xia X, Su C, Dong W, Xian Y, Wang W, et al. Hepatotoxicity and genotoxicity of patulin in mice, and its modulation by green tea polyphenols administration. Food Chem Toxicol. 2014;71:122-7.

26. Scheller J, Ohnesorge N, Rose-John S. Interleukin-6 transsignalling in chronic inflammation and cancer. Scand J Immunol. 2006;63:321-9.

27. Wichmann G, Herbarth O, Lehmann I. The mycotoxins citrinin, gliotoxin, and patulin affect interferon-gamma rather than interleukin-4 production in human blood cells. Environ Toxicol. 2002;17:211-8.

28. Seidelin JB, Bjerrum JT, Coskun M, Widjaya B, Vainer B, Nielsen OH. IL-33 is upregulated in colonocytes of ulcerative colitis. Immunol. Lett. 2010;128:80-5.

29. Gabay C. Interleukin-6 and chronic inflammation. Arthritis Res. Ther. 2006:8(2):2-8.

30. Gaini S, Koldkjaer OG, Pedersen C. Procalcitonin, lipopolysaccharide-binding protein, interleukin- 6 and C-reactive protein in community-acquired infections and sepsis: a prospective study. Crit Care. 2006:10:53.

31. Ishihara K, Hirano T. IL-6 in autoimmune disease and chronic inflammatory proliferative disease. Cytokine Growth Factor Rev. 2002;13:357-68.

32. Kishimoto T. IL-6: from its discovery to clinical applications. Int Immunol. 2010;22(5):347-52

33. Scheller J, Ohnesorge N, Rose-John S. Interleukin- 6 transsignalling in chronic inflammation and cancer. Scand J Immunol. 2006;63:321-9.

34. Bondy GS, Pestka JJ. Immunomodulation by fungal toxins. J Toxicol Environ Health. 2000;3(2):109-43.

35. Dziennik Urzędowy Unii Europejskiej. L50/8 z 27.02.2010.

36. Gashlan HM. Biochemical Studies of Patulin on Liver Functions in Male Albino Mice. J Apple Anim Res. 2008;34(1):93-6.

37. Walusia J, Gutarowska B, Żakowska Z, Pałczyński C. Grzyby Pleśniowe w środowisku komunalnym i w miejscu pracy - istotne zagrożenie zdrowotne. Medycyna Pracy. 2004;55(3):257-66.

38. Luft P, Oostingh GJ, Gruijthuijsen Y, Horejs-HoeckJ, Lehmann I, Duschl A. Patulin Influences the Expression of Th1/Th2 Cytokines by Activated Peripheral Blood Mononuclear Cells and T Cells Through Depletion of Intracellular Glutathione. Environ Toxicol. 2008;23:84-95.

39. Puel O, Tadrist S, Delaforge M, Oswald IP, Lebrihi A. The inability of Byssochlamys fulva to produce patulin is related to absence of 6-methylsalicylic acid synthase and isoepoxydon dehydrogenase genes. Int J Food Microbiol. 2007;115:131-9.

40. Gabay C. Interleukin- 6 and chronic inflammation. Arthritis Res. Ther. 2006;8(2):2-8.

41. Ishihara K, Hirano T. IL-6 in autoimmune disease and chronic inflammatory proliferative disease. Cytokine Growth Factor Rev. 2002;13:357-68.

42. Urbanowicz W. Rola wątroby w odpowiedzi ostrej fazy. Postępy Nauk Medycznych. 2000;1:46-9.

43. Andrews NC. Anemia of inflammation: the cytokine-hepcidin link. J Clin Invest. 2004;113:1251-3.

44. Koczy-Baron E, Kasperska-Zając A. Rola naczyniowo-śródbłonkowego czynnika wzrostu w procesach zapalnych. Postępy Hig Med Dośw. 2014;68:57-65.

45. Zhang Y, Matsuo H, Morita E. Increased production of vascular endothelial growth factor in the lesions of atopic dermatitis. Arch Dermatol Res. 2006;297:425-9. 